\title{
Kajian tentang Kegiatan Cooking Class Dalam Meningkatkan Keterampilan Motorik Halus Anak Usia 5-6 Tahun
}

\author{
Julaeha Rasid1, Rosita Wondal'2, Rita Samad ${ }^{3}$ \\ 1, PG PAUD FKIP universitas khairun ternate \\ Jl, Bandara Sultan Babullah Kota Ternate Utara,Kode Pos 53 Ternate 97728 \\ Email: julaeharasid29@gmail.com
}

\begin{abstract}
Abstrak:
Keterampilan motorik halus merupakan suatu kemampuan individu yang beraktivitas dengan menggunakan otot-otot halus. motorik halus merupakan salah satu aspek perkembangan anak yang wajib dikembangkan. Motorik halus anak dapat dikembangkan melalui kegiatan kelas memasak (cooking class). melalui penelitian kajian pustaka yang dilakukan, peneliti dapat menyimpulkan bahwa Kegiatan cooking class merupakan suatu aktivitas yang menyenangkan bagi anak serta dapat meningkatkan kemampuan motorik halus anak. Kegiatan cooking class selain dapat meningkatkan pengalaman belajar anak secara langsung. Melalui kegiatan ini dapat mengenalkan bahan makanan, cara mengolah makanan, perpaduan warna, juga dapat melatih keterampilan motorik halus anak, melalui gerakan memotong, meremas, membentuk dan mencetak. Berdasarkan hasil kajian ini diharapkan kepada guru untuk dapat menjalankan kegiatan cooking class ini dengan menggunakan bahan-bahan yang ada disekitar, serta memperhatikan unsur keselamatan bagi anak.
\end{abstract}

Kata kunci: Motorik halus, cooking class

\begin{abstract}
Fine motor skills are the abilities of individuals who use smooth muscles. Fine motor is one aspect of child development that must be developed. Fine motor skills can be developed through cooking class activities. Through library research, researchers conclude that cooking class activities representing activities that are fun for children to improve children's fine motor skills. Besides, it is able to enhance children's learning experience directly through activities, but also introducing food ingredients, how to process food, and color combination. It trains the children fine motor skills, through the movements of cutting, squeezing, making and printing. Based on the results of the study it is expected for teachers who can carry out cooking class activities using available materials, and pay attention to children safety.
\end{abstract}

Key words: fine motor skills, cooking class 


\section{A. Pendahuluan}

Pendidikan merupakan upaya mengembangkan potensi anak agar dapat berkembang secara optimal. Pada lembaga pendidikan anak usia dini proses pemberian rangsangan pendidikan dilakukan dengan tujuan agar potensi yang ada pada anak dapat berkembang secara optimal. Pada usia ini (lahir sampai enam tahun) anak sedang mengalami masa golden ages atau masa keemasan di mana sel syarat otak sedang mengalami perkembangan yang sangat pesat. Pada masa ini perkembangan anak tidak dapat terulang kembali, masa sensitif dan berkembangnya seluruh aspek perkembangan anak, yang nantinya akan menjadi dasar bagi perkembangan selanjutnya. Pada satu sisi kemampuan anak untuk tumbuh dan berkembang tidak dapat hadir begitu saja. Ada proses atau tahapan-tahapan yang harus dilaluinya, yang di dalamnya diperlukan stimulus-stimulus dari lingkungannya untuk mendukung perkembangannya. Hal ini akan mempengaruhi seluruh aspek perkembangan anak. Pentingnya menciptaan proses pembelajaran yang baik wajib dilakukan oleh pendidik agar hasil belajar anak menjadi lebih bermakna sehingga hasil belajar anak dapat difungsikan dalam kehidupan anak sehari-hari secara nyata.

Kegiatan cooking class atau kelas memasak merupakan bagian dari medel kontekstual yang biasa dilakukan oleh guru anak usia dini. Cooking class adalah salah satu kegiatan menyenangkan yang secara langsung melibatkan anak untuk bergerak dan berkreasi dengan menggunakan jari-jari tangan mereka. Permainan memasak merupakan suatu kegiatan untuk mengembangkan keterampilan memasak dan cara pembuatannya dengan menggunakan bahan-bahan yang sesungguhnya dan hasil dapat dinikmati oleh anak. Beberapa contoh dari kegiatan cooking class menyeduh susu, teh, atau sirup, membuat jus, mamasak nasi, merebus sayur-sayuran dan lainlain. Kegiatan ini dilakukan tentu dengan melibatkan otot-otot kecil anak serta koordinasinya dengan mata atau dengan kata lain motorik halus anak. Motorik halus anak merupakan salah satu perkembangan anak yang penting untuk dikembangkan. Wati (2016) mengungkapkan bahwa pelaksanaan kegiatan belajar mengajar di TK, dibutuhkan kegiatan motorik halus yang diajarkan kepada anak sejak prasekolah karena sangat penting bagi anak usia dini. Fungsi motorik halus sebenarnya bukan sekedar untuk melatih keterampilan gerak kedua tangan akan tetapi untuk mengembangkan aspek perkembangan anak, terutama mengembangkan koordinasi kecepatan tangan dengan gerakan mata dan melatih penguasaan emosi.

Juniyanasari (2015) melakukan penelitian dengan hasil penelitian menunjukkan bahwa pada siklus I rata-rata persentase keterampilan motorik halus adalah $69,79 \%$ berada pada katagori sedang, sedangkan terjadi peningkatan pada siklus II menjadi 80,99\% dengan katagori tinggi, hal tersebut menandakan bahwa terdapat peningkatan rata-rata persentase keterampilan motorik halus pada anak kelompok B PAUD ABC Singaraja pada siklus I dan siklus II sebesar 11,2\%. Jadi penerapan pembelajaran kontekstual melalui cooking class dapat meningkatkan keterampilan motorik halus pada anak kelompok B PAUD ABC Singaraja semester II tahun pelajaran 2014/2015. Wahyuni (2018) juga menyimpulkan dari hasil penelitiannya yakni terjadi peningkatan kemampuan motorik anak usia 5-6 tahun kegitana cooking class mulai dari observasi yang dilakukan pada tahapan pra siklus mengalami peningkatan dalam setiap siklusnya. Hal ini dapat dilihat dari perolehan angka mulai dari pra siklus sampai siklus II. Dimana perolehan angka rata-rata pra siklus sebesar $39.46 \%$, siklus I sebesar 53,99\%, dan tingginya peningkatan kemampuan motorik halus melalui kegiatan cooking class dari awal pra siklus sampai pada siklus II mengalami peningkatan yang cukup signifikan yaitu sebesar $77.46 \%$. Jannah (2017) melakukan penelitian action research dengan tujuan untuk meningkatkan kemampuan motorik halus melalui kegiatan memasak, dengan subjek penelitian anak kelompok A1 di TK Al-Fitroh Surabaya dengan jumlah 22 anak terdiri 
dari 11 anak laki-laki dan 11 anak perempuan. Teknik pengumpulan data yang digunakan pada penelitiannya yakni observasi dan dokumentasi. Hasil penelitian menunjukkan adanya peningkatan kemampuan motorik halus anak melalui kegiatan memasak diantaranya kemampuan anak meremas adonan pada siklus I sebesar 63,6\% meningkat pada siklus II menjadi 88,3\%, kemampuan anak menggulung adonan pada siklus I sebesar $63,7 \%$ meningkat pada siklus II menjadi $90,9 \%$, dan kemampuan anak menekan/mencetak adonan pada siklus I sebesar 63,7\% meningkat pada siklus II menjadi 90,9\%. Kesimpulan yang didapatkan yakni kegiatan memasak dapat meningkatkan kemampuan motorik halus pada anak kelompok A1 di TK Al-Fitroh Surabaya.

Perkembangan fisik motorik pada anak usia dini berkembang sangat pesat. Oleh karena itu harus diberikan stimulus yang tepat agar dapat mencapai perkembangan yang optimal. Tak dapat dipungkiri bahwa ketrampilan motorik halus yang dimiliki setiap anak berbeda-beda, baik dalam hal kekuatan, kelincahan maupun ketepatannya. Perbedaan ketrampilan motorik halus ini dipengaruhi oleh pembawaan anak dan stimulasi yang didapatkan anak di rumah maupun di lingkungan sekolah. Lingkungan sekitar anak mempunyai pengaruh yang lebih besar dalam kemampuan motorik halus. Gerakan motorik halus hanya melibatkan bagian-bagian tubuh tertentu saja dan dilakukan oleh otot-otot kecil, seperti keterampilan menggunakan jari jemari tangan dan gerakan pergelangan tangan yang tepat. Oleh sebab itu diperlukan peran orangtua maupun guru di lembaga PAUD untuk bekerja sama dalam mengoptimalkan perkembangan motorik halus anak segingga berkembang optimal seperti yang diharapkan guna mempersiapan anak dalam menulis kelak.

Berdasarkan kenyataan dilapangan, khususnya pada lembaga pendidikan anak usia dini di Maluku Utara kegiatan cooking class masih tergolong jarang dilakukan terutama pada lembaga PAUD di pedesaan. Hal ini mungkin disebabkan karena factor biaya maupun kerumitan pada kegiatan ini. Tujuan dari kajian literatur ini adalah untuk mengkaji tentang kegiatan cooking class dalam meningkatkan keterampilan motorik halus anak usia 5-6 tahun.

\section{B. Metode Penelitian}

Metode yang digunakan dalam penelitian ini dengan pendekatan studi literatur (library reseach). Menurut Zeed Mestika (2014) menyatakan bahwa metode penelitian dengan pendekatan study literatur merupakan penelitian yang serangkaian kegiatannya dengan metode pengumpulan data pustaka, buku-buku, serta tulisan yang terkait dengan judul penelitian ini.

\section{Pembahasan}

\section{Perkembangan fisik Motorik}

Perkembangan fisik motorik merupakan hal yang menjadi dasar bagi kemajuan perkembangan berikutnya, ketika fisik anak berkembangan dengan baik maka anak dapat mengembangkan kemampuan fisiknya dengan tanpa bantuan orang lain. Perkembangan fisik ini ditandai dengan kemampuan perkembangan motorik halusnya. (Moeslichatoen, 2010: 61)

Gerakan motorik halus merupakan suatu kemampuan individu yang beraktivitas dengan menggunakan otot-otot halus dimana perkembangan motorik halus dipengaruhi oleh susunan syaraf pusat dan juga otot-otot yang saling terkoordinasi satu sama lain, sehingga semakin matangnya sistem syaraf pusat pada anak maka akan menghasilkan suatu gerakan halus yang terkoordinasi dengan sangat baik pula. Kemampuan motorik halus adalah aktivitas motorik yang melibatkan aktivitas otot-otot kecil (halus), gerakan ini menuntut koordinasi mata, 
tangan dan kemampuan pengendalian gerak yang baik dan memungkinkan untuk melakukan suatu ketepatan dan kecermatan dalam gerakannya. Sedangkan yang termasuk dalam aktivitas ini antara lain memegang benda kecil, meronce, Menggunting, menulis, meremas, mencatak, mengikat tali sepatu, mengkancingkan baju dan lain sebagainya.

Suyanto (2005) menyatakan bahwa keterampilan motorik halus adalah pengorganisasian penggunaan sekelompok otot-otot kecil seperti jari jemari dan tangan yang sering membutuhkan kecermatan dan koordinasi mata dengan tangan, keterampilan yang mencakup pemanfaatan dengan alat-alat untuk bekerja dan objek yang kecil atau pengontrolan terhadap mesin misalnya mengetik, menjahit dan lain-lain.

Gerakan motorik halus mempunyai peran yang sangat penting, motorik halus adalah gerakan yang hanya melibatkan bagian-bagian tubuh tertentu yang dilakukan oleh otot-otot kecil saja. Oleh karena itu gerakan didalam motorik halus tidak membutuhkan tenaga akan tetapi membutuhkan koordinasi yang cermat serta teliti (Depdiknas, 2008).

Sumantri (2005) menyatakan bahwa keterampilan motorik halus adalah pengorganisasian penggunaan sekelompok otot-otot kecil seperti jari -jemari dan tangan yang sering membutuhkan kecermatan dan koordinasi dengan tangan,keterampilan yang mencakup pemanfaatan menggunakan alat-alat untuk mengerjakan suatu objek.

Hal yang sama dikemukan oleh Yudha dan Rudyanto (2005:118), menyatakan bahwa motorik halus (kecil) seperti menulis,merema, menggambar, menyusun balok dan memasukkan kelereng. Demikian pula menurut Sujiono (2008:125) menyatakan bahwa motorik halus adalah gerakan yang hanya melibatkan bagian-bagian tubuh tertentu saja dan dilakukan oleh otot-otot kecil, seperti keterampilan menggunakan jari-jemari tangan dan gerakkan oergelangan tangan yang tepat. oleh karena itu, gerakkan ini tidak terlalu membutuhkan tenaga, namun gerakan ini membutuhkan koordinasi mata dan tangan yang cerma.semakin baiknya gerakan motorik halus anak membuat anak dapat berkreasi, seperti menggunting, kertas, menggambar, mewarnai, serta menganyam, Namun tidak semua anak memiliki kematangan untuk menguasai kemampuan ini pada tahap yang sama.

Magil Richard (2008: 103) mengatakan bahwa keterampilan motorik halus merupakan keterampilan yang memerlukan kontrol dari otot-otot kecil dari tubuh untuk mencapai tujuan dari keterampilan. Secara umum, keterampilan ini meliputi koordinasi mata tangan. Keterampilan ini membutuhkan derajat tinggi dari kecermatan gerak untuk menampilkan suatu kecakapan. Contonnya yaitu menulis, melukis, menjahit, dan mengancingkan baju.

Hurlock (2003:150) mengatakan motorik halus merupakan kemampuan anak melakukan berbagai aktivitas dengan menggunakan otot halusnya seperti mengenggam, menulis, menggunting, meremas, dll. Gerakan ini tidak terlalu menggunakan banyak tenaga, akan tetapi hanya memerlukan koordinasi mata dan tangan dengan teliti.

Sementara itu, Santrock (2007 : 216) Mengatakan bahwa keterampilan motorik halus yang dimiliki setiap anak berbeda-beda,baik dalam hal kekuatan maupun ketepatannya. Perbedaan ini juga dipengaruhi oleh pembawaan anak dan stimulasi yang didapatkannya. Lingkungan sekitar anak mempunyai pengaruh yang lebih besar dalam kecerdasan motorik halusnya.

Kemampuan motorik halus yang dimiliki setiap anak berbeda. Ada yang lambat dan ada pula yang sesuai dengan perkembangan tergantung pada kematangan anak. Namun sebaiknya selaku pendidik atau orang tua hendaknya mengetahui permasalahan dan memberikan solusi bagaimana meningkatkan 
kemampuan motorik halus pada anak. Stimulasi perkembangan motorik halus bertujuan melatih jari-jemari anak untuk persiapan menulis, seperti menggunting, menjiplak, memotong, menggambar, menempel, mewarnai dan meronce perlu diberikan kepada anak agar kemampuan motorik halusnya berkembang dengan baik. Stimulasi perkembangan motorik halus bertujuan melatih jari-jemari anak untuk persiapan menulis, seperti menggunting, menjiplak, memotong, menggambar, menempel, mewarnai dan meronce perlu diberikan kepada anak agar kemampuan motorik halusnya berkembang dengan baik (Darwati, 2019).

Yudha M. Saputra dan Rudyanto (2005) mengatakan bahwa perkembagan motorik adalah suatau perubahan dalam perilaku motorik yang memperhatikan interaksi dari kematangan makhluk dan lingkungannya. Pada manusia perkembangan motorik merupakan perubahan kemampuan motorik dari bayi samapi dewasa yang melibatkan berbagai aspek perilaku dan perkembangan motorik saling mempengaruhi satu sama lain.

Tujuan kemampuan motorik halus di antaranya adalah: 1) saat anak mengembangkan kemampuan motorik halusnya diharapkan anak dapat menyesuaikan lingkungan sosial dengan baik serta menyediakan kesempatan untuk mempelajari keterampilan sosialnya karena setiap pengembangan tidak dapat terpisah satu sama lain; 2) Meningkatkan keterampilan motorik halus anak kelompok B, agar mampu mengembangkan keterampilan motorik halus khususnya koordinasi mata dan tangan secara optimal; 3) semakian banyak anak melakukan sendiri suatu kegiatan maka semakin besar juga rasa kepercayaan dirinya.

Daeng Sari (2004) menjelaskan bahwa motorik halus adalah aktivitas motorik yang melibatkan aktivitas otot-otot kecil atau halus. Gerakan ini menuntut koordinasi mata dan tangan serta pengendalian gerak yang baik yang memungkinkan melakukan ketepatan dan kecermatan dalam gerak otot-otot halus.selain itu, dibutuhkan konsetrasi sehingga kegiatan yang dilakukan anak dapat berjalan maksimal.

Menurut lindya (2008: 6) motorik halus yang aspek yang berhubungan dengan kemampuan anak untuk melakukan gerakan pada bagian-bagian tubuh tertentu saja dan dilakukan oleh otot-otot kecil tetapi memerlukan koordinasi yang cermat.

Menurut Sumantri (2005: 146) menambahkan bahwa perkembangan motorik anak adalah suatu proses kematangan yang berhubungan dengan aspek defenisial bentuk atau fungsi termasuk perubahan sosial emosional. Proses motorik adalah gerakan yang langsung melibatkan otot untuk bergerak dan proses persyaratan yang menjadikan seseorang mampu menggerakkan anggota tubuhnya (tangan, kaki dan anggota tubuhnya).

Berdasarkan kutipan- kutipan diatas, maka pengertian motorik halus adalah pengorganisasian penggunaan otot-otot kecil seperti jari-jemari dan tangan yang sering membutuhkan kecermatan koordinasi mata dan tangan.

Perkembangan kemampuan motorik dipengaruhi oleh berbagai faktor yang mencakup kesiapan belajar, kesempatan belajar, kesempatan berpraktek, model yang baik, bimbingan, dan motivasi. Pertumbuhan kemampuan motorik, baik motorik kasar maupun motorik halus pada anak tidak akan berkembang melalui kematangan begitu saja, melainkan harus dipelajari. Faktor- Faktor yang mempengaruhi perkembangan motorik halus anak menurut Mahendra (dalam Sumantri, 2005: 143 ) antara lain:

a. Faktor hereditas (warisan sejak lahir atau bawaan)

b. Faktor lingkungan yang mengutungkan atau merugikan kematangan fungsi- fungsi organis dan fungsi psikis 
c. Aktivitas anak sebagai subyek bebas yang berkemauan, kemampuan, punya emosi serta mempunyai usaha untuk membangun diri sendiri.

Karakteristik perkembangan motorik halus dapat dijelaskan dalam (Depdiknas,2007) sebagai berikut:

1. Pada saat anak berusia tiga tahun

Pada saat anak berusia tiga tahun kemampuan gerakan halus pada masa bayi. Meskipun anak pada saat ini sudah mampu menjumput benda dengan menggunakan jempol dan jari telunjuknnya tetapi gerakan itu sendiri masih kaku.

2. Pada usia empat tahun

Pada usia empat tahun koordinasi motorik halus anak secara subtansi sudah mengalami kemajuan dan gerakannya sudah lebih cepat bahkan cenderung ingin sempurna.

3. Pada usia lima tahun

Pada usia lima tahun koordinasi motorik halus anak sudah lebih sempurna lagi tangan, lengan, dan tubuh bergerak dibawah koordinasi mata. Anak juga telah mampu membuat dan melaksanakan kegiatan yang lebih majemuk, seperti kegiatan proyek.

4. Pada akhir masa kanak-kanak usia enam tahun

Pada akhir masa kanak-kanak usia enam tahun ia telah belajar bagaimana menggunakan jari jemarinya dan pergelangan tangannya untuk menggerakkan ujung pensilnya.

\section{Cooking Class (kelas masak)}

Cooking class adalah suatu kegiatan memasak yang dilakukan secara berkelompok dalam sebuah tempat untuk mengolah dan memasak dengan cara lebih terkonsep dengan benar (Sujiono, 2009 :63).

Tujuan dari kegiatan cooking class ini menurut Montolalu (2005: 315 ) yaitu :

a) Mengembangkan ekspresi melalui berbagai media dengan gerakan tangan

b) Mengembangkan fantasi, imajinasi / jari, koordinasi otot dan mata

c) Melatih kecakapan mengkombinasi warna

d) Menunjuk perasaan terhadap gerakan tangan

e) Mengembangkan motorik halus anak.

Kegiatan cooking class berdasarkan pendapat dari Pramita, (2014: 47) Merupakan wahana yang tepat untuk anak usia dini yang mampu menumbuhkan dan meningkatkan pengalaman belajar anak secara langsung. Dalam kegiatan ini anak dapat mengenalkan bahan makanan, mengolah makanan, perpaduan warna, bahkan dapat melatih motorik halus anak, melalui gerakan memotong, meremas, membentuk dan mencetak. Sedangkan Menurut Bartono dkk, (2006: 15) menyatakan bahwa memasak adalah membuat suatu bahan mentah menjadi matang dengan tujuan agar dapat dimakna sesuai dengan naluri manusia. Dengan kata lain mengolah bahan mentah menjadi matang yang siap untuk di hidangkan dengan maksud atau tujuan tertentu. Menurut Sukerti (2008: 63) tujuan dari cooking class adalah belajar membuat makanan itu lebih mudah dicerna dalam perut, meningkatkan pengetahuan dan keterampilan tentang seni memasak, melatih mengolah makanan dengan berbagai teknik, dan mengetahui cara membuat makanan itu aman untuk dikonsumsi.

Menurut Iskandar (2005: 71) dalam teori cooking class memiliki istilah-istilah sebagai dasar dalam teknik memasak sederhana. Istilah-istilah dasar memasak juga melatih gerak tangan seseorang dalam seni memasak seperti menusuk, memotong mememarkan, meremas dan mencincang.

Enion dalam Apriliana ( 2015:14) berpendapat bahwa cooking class adalah ilmu pengetahuan yang mengandung keterampilan dan pramita (dalam Indrawat, tanpa tahun : 5) berpendapat bahwa cooking class merupakan wahana yang tepat 
untuk anak TK yang mampu menumbuhkan dan meningkatkan pengalaman belajar anak secara langsung. Kegiatan cooking class adalah kegiatan untuk mengembangkan keterampilan memasak dengan menggunakan bahah-bahan yang sesungghnya dan hasil dapat dikmat langsung oleh anak.

Terdapat 3 tahap pembelajaran dalam kegiatan cooking class yaitu :

1. Persiapan

Tahap pertama yang dilakukan yaitu guru menjelaskan kegiatan cooking class yang akan dilakukan, misalnya menghias kue donat. Guru dan anak mempersiapkan alat dan bahan yang akan digunakan untuk kegiatan cooking class. Anak menggali informasi tentang kegunaan dari setiap alat dan bahan. Informasi tersebut dapat diperoleh dari buku maupun guru secara langsung menerangkan kepada anak tentang kegunaan dari masing-alat dan bahan makanan yang akan digunakan.

2. Pelaksanaan

Tahap pelaksanaan dilakukan yakni terlebih dahulu guru menjelaskan dan memberi contoh teknik mengias donat. Misalnya cara memegang donat dan cara mengambil kream hiasan donat serta cara menghias donat sesuai denga kreasi dari masing-masing anak.

3. Penyelesaian

Pada tahap ini anak dipersilakan untuk menyajikan produk kegiatan cooking class. Setelah kegiatan selesai anak melakukan cleaning up atau membersihkan ruangan yang digunakan untuk kegiatan cooking class. Kemudian guru mempersilakan kepada anak untuk menceritakan proses dan hasil yang telah dilakukan saat kegiatan cooking class.

\section{Karakteristik Anak Usia 5-6 Tahun}

Berdasarkan Tingkat Pencapaian Perkembangan yang telah dirumuskan dalam Peraturan Peraturan Menteri Pendidikan Dan Kebudayaan Republik Indonesia Nomor 137 Tahun 2014 Tentang Standar Nasional Pendidikan Anak Usia Dini telah mencapai perkembangan motorik halus sebagai berikut :

Tabel 1. Tingkat Pencapaian Perkembangan Motorik Halus Anak

\begin{tabular}{|c|c|c|}
\hline \multirow{2}{*}{$\begin{array}{c}\text { Lingkup } \\
\text { Perkembangan }\end{array}$} & \multicolumn{2}{|c|}{ Tingkat Pencapaian Perkembangan Anak } \\
\hline & Usia 4 - 5 tahun & Usia 5 -6 tahun \\
\hline Motorik Halus & $\begin{array}{l}\text { 1. Membuat garis vertikal, } \\
\text { horizontal, lengkung kiri/kanan, } \\
\text { miring kiri/kanan, dan lingkaran } \\
\text { 2. Menjiplak bentuk } 3 . \\
\text { Mengkoordinasikan mata dan } \\
\text { tangan untuk melakukan gerakan } \\
\text { yang rumit } 4 \text {. Melakukan gerakan } \\
\text { manipulatif untuk menghasilkan } \\
\text { suatu bentuk dengan } \\
\text { menggunakan berbagai media } 5 . \\
\text { Mengekspresikan diri dengan } \\
\text { berkarya seni menggunakan } \\
\text { berbagai media } 6 \text {. Mengontrol }\end{array}$ & $\begin{array}{l}\text { 1. Menggambar sesuai } \\
\text { gagasannya 2. Meniru bentuk } \\
\text { 3. Melakukan eksplorasi } \\
\text { dengan berbagai media dan } \\
\text { kegiatan 4. Menggunakan alat } \\
\text { tulis dan alat makan dengan } \\
\text { benar } 5 \text {. Menggunting sesuai } \\
\text { dengan pola } 6 . \text { Menempel } \\
\text { gambar dengan tepat } 7 . \\
\text { Mengekspresikan diri melalui } \\
\text { gerakan menggambar secara } \\
\text { rinci }\end{array}$ \\
\hline
\end{tabular}




\begin{tabular}{|c|c|}
\hline & $\begin{array}{lrr}\text { gerakan } & \text { tangan } & \text { yang } \\
\text { meggunakan } & \text { otot } & \text { halus } \\
\text { (menjumput, } & \text { mengelus, } \\
\text { mencolek, mengepal, memelintir, } \\
\text { memilin, memeras) }\end{array}$ \\
\hline
\end{tabular}

Beberapa hasil penelitian menunjukan bahwa dengan program kegiatan cooking class bagi anak usia dini di Kelas Koki Cilik. Data dikumpulkan melalui proses wawancara, observsi dan studi dokumentasi. Dari hasil penelitian dapat disimpulkan bahwa: jika di tinjau dari segi perencanaan, pelaksanaan dan evaluasi progrram kegiatan Cooking Class bagi anak Usia Dini yang dilakukan di Kelas Koki Cilik dapat meningkatkan aspek perkembangan anak usia dini terutama perkembangan motorik halus anak (Nurhapita 2019: 2460). Hal ini sesuai dengan hasil penelitian dari Darwati dkk, (2019: 1) menunjukkan bahwa : 1) Proses pelaksanaan kegiatan fun cooking dalam meningkatkan kemampuan motorik halus anak pada kelompok bermain Flamboyan Pangkur Ngawi meliputi:a) koordinasi antara tangan dan mata; b) memegang alat dan bahan dengan benar; c) mengolah bahan dengan benar yang dilakukan sebanyak 6 pertemuan dalam 2 siklus ; 2) Kegiatan fun cooking dapat meningkatkan kemampuan motorik halus anak sebesar $80 \%$ dengan hasil pada ; a) pratindakan diperoleh $0 \%$ atau belum ada anak dari 15 anak berada pada kriteria berkembang sangat baik, b) siklus I diperoleh 13,3\% atau 2 anak dari 15 anak yang berada pada kriteria berkembang sangat baik, c) siklus II diperoleh $80 \%$ atau 12 anak dari 15 anak yang kemampuan motorik halusnya berada pada kriteria berkembang sangat baik. Anggraheni (2019) mengungkapkan bahwa manfaat dari kegiatan cooking classantara laindapat mengenalkan bahan makanan, kandungan gizi dan manfaatnya untuk tumbuh kembang anak-anak melatih motorik halus anak dan mengembangkan kreativitas anak melalui menghias piring saji sesuai dengan kreasi anak.

Berdasarkan kajian literatur dapat disimpulkan bahwa kagiatan cooking class terbukti dalam mengembangkan motorik halus anak. Kaitan cooking class dalam mengembangkan motorik halus anak terletak pada proses kegiatan masak dimana otot-otot kecil anak dapat difungsikan dengan baik, terkoodinasi dengan mata anak sehingga anak dapat menyelesaikan kegiatan masak di kelas. Kegiatan cooking class dapat mengembangkan motorik halus anak terlihat jelas saat anak memegang alatalat masak, anak menggunakan alat-alat masak sesuai dengan fungsinya (memotong, menumbuk ata menggiling, mengiris, mengaduk dan sebagainya). Kegiatan cooking class dapat dikemas dengan cara yang sederhana dan menyenangkan serta aman bagi anak, dengan menggunakan peralatan yang ramah anak serta pengawasan dari orang tua. Berikut ini adalah suasana kegiatan cooking class di lembaga PAUD: 


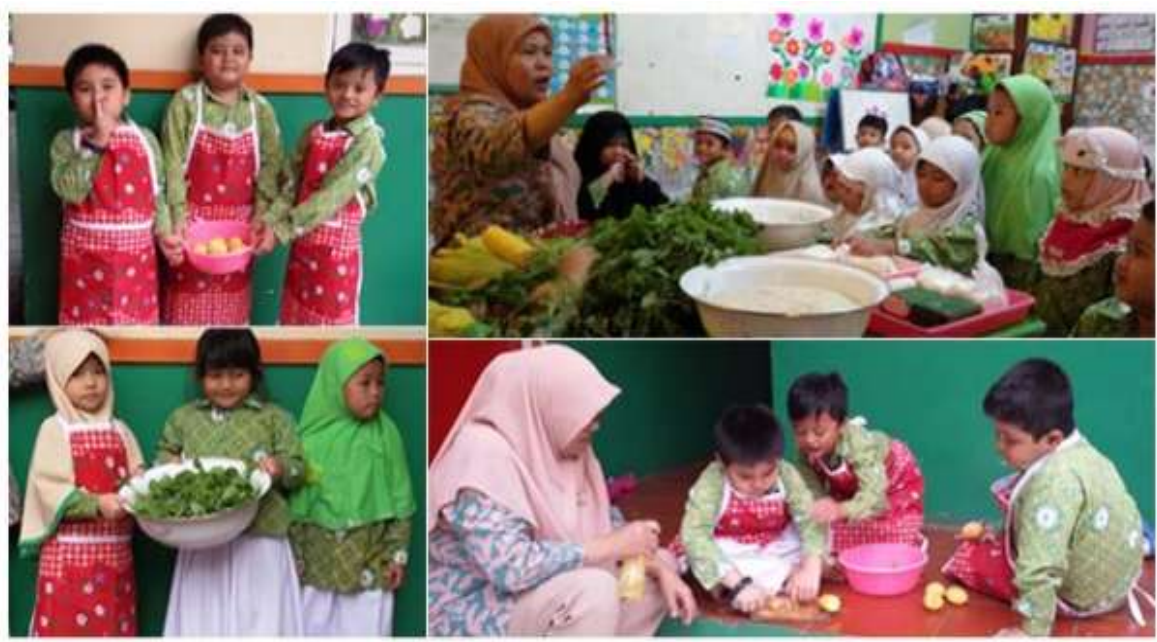

Gambar : Kegiatan Cooking Class di Lembaha PAUD

\section{Simpulan}

Dari kajian literatur yang dilakukan, peneliti dapat menyumpulkan bahwa kegiatan cooking class merupakan suatu aktivitas yang menyenangkan bagi anak serta dapat meningkatkan kemampuan motorik halus anak yang tercermin dalam kegiatankegiatan masak yang dilakukan anak bersama guru pada lembaga PAUD. Melalui kajian ini diharapkan kepada guru untuk dapat menjalankan kegiatan cooking class ini dengan menggunakan bahan-bahan yang ada disekitar, serta memperhatikan unsur keselamatan bagi anak. bagi orang tua dirumah juga dapat melibatkan anak usia dini dalam kegiatan memasak di rumah, walau anak masih dalam tahap perkembangan sehingga tugas memasak dirumah dapat disesuaikan dengan perkembangan dan keamanan anak.

\section{DAFTAR PUSTAKA}

Aprilliana, 2015. Meningkatkan Kecerdasan Atau Keterampilan Melalui Kegiatan Cooking Class Di Kelompok B TK Amanah Tahun Pelajaran 2014/2015. skripsi. jember. fakultas keguruan dan ilmu pendidikan universitas Muhammadiyah jember.

Anggraheni Ika, 2019. Profil Perkembangan Motorik Halus Dan Kreativitas Anak Kelompok B Dalam Kegiatan Cooking Class, THUFULI: Jurnal Pendidikan IslamAnak Usia Dini, VolumeINomor 1Tahun 2019

Bartono, P.H. 2006. Dasar-Dasar Food Product.Yogyakarta: C.V Andi Offset.

Depdiknas. 2008. Pengembangkan Model pembelajaran Tatap Muka penugasan Terstruktur dan Tugas Mandiri Tidak Terstruktur. Jakarta. Direktorat pembinaah sekolah Dasar.

Daeng Sari. 2004. Metode Mengajar di Taman kanak-kanak. Depdikbud.

Darwati, Elisa Novie Azizah, Arwendis Wijayanti, 2019. Peningkatan Kemampuan Motorik Halus Anak Usia Dini Melalui Kegiatan Fun Cooking, Jurnal Ilmiah Pendidikan Citra Bakti. Vol 6 No 2

Hurlock, 2003. Psikologi Perkembangan jakarta: Penerbit Erlangga

Jannah Fitri Freeanti Noor, 2017. Meningkatkan Motorik Halus Anak Melalui Kegiatan Cooking (Memasak) di Kelompok A1 TK Al-Fitroh Surabaya, Jurnal PAUD Teratai. Volume 06 Nomor 3 Tahun 2017

Juniyanasari Put, Ketut Pudjawan, Putu Rahayu Ujianti, 2015. Penerapan Pembelajaran Kontekstual Melalui Cooking Class Untuk Meningkatkan Keterampilan Motorik 
Halus Pada Anak. e-Journal Universitas Pendidikan Ganesha Jurusan Pendidikan Guru Pendidikan Anak Usia Dini (Volume 3 No. 1-Tahun 2015)

Montolalu, dkk, 2005. Bermain Dan permainan Anak, jakarta: UT

Nurhapita Anisa, Enoh, Dinar Nur Inten. 2019. Program Kegiatan Coking Class untuk Anak Usia Dini di Kelas Koki Cilik Jakarta Cooking Class Activity for Early Childhood in Kelas Koki Cilik Jakarta . Prosiding Pendidikan Guru PAUD ISSN: 2460-6421 81, Volume 5, No. 2, Tahun 2019

Pramita, 2014. Seri Memasak Femina Cooking With Kids, jakarta: Gaya Favorit Press.

Sumantri, 2005. Pengembangan keterampilan Motorik Anak Usia Dini. Jakarta: Dinas pendidikan

Sujiono, yuliani, Nurani 2009. Konsep Dasar Pendidikan Anak Usia Dini. Jurnal PAUD Potensi Vol 6 Nor 3 Tahun 2017.

Sumantri, 2005:146. Model Pengembangan Keterampilan Motorik Anak Usia Dini. Jakarta: Depdiknas.

Suyanto, S. (2005).Dasar-dasar pendidikan anak usia dini. Yogyakarta: Hikayat Publishing Santrock, J.W. 2007. Perkembangan Anak Jilid I. Jakarta: Erlangga.

Wahyuni Sri, Sean Marta Efastri, Siti Fadillah, 2018. Meningkatkan Kemampuan Motorik Halus melalui Kegiatan Cooking Class Anak Usia 5-6 Tahun di TK Melati Pekanbaru, Vol. 2 No. 01 (2018): PAUD Lectura - Jurnal Pendidikan Anak Usia Dini /Articles

Wati Uci Kartika dan Ellya Atik Rakhmawati, 2016. Meningkatkan Motorik Halus Melalui Kegiatan Memasak Pada Siswa Kelompok B TK Kartika III-41 Demak Tahun Ajaran 2015 / 2016. Article · July 2016DOI: 10.26877/paudia.v5i1.1176

Yudha M Saputra dan Rudyanto, 2005. Pembelajaran koperatif untuk meningkatkan keterampilan Anak TK. Jakarta: Depdiknas, Dikti, Direktorat P2TKPT.

Zeed Mestika, 2014. Metode Penelitian Kepustakan, Jakatra: Yayasan Pustaka Obor. 